Людмила И. ДАНИЛЕНКО

DOI: $10.14746 / b o .2020 .1 .4$

Киевский национальный университет

имени Тараса Шевченко

\section{Чешский фразеологизм modré pondělí 'синий понедельник' на иноязычном фоне: от архаики до неологии}

Keywords: phraseology, etymology, Czech-German contacts, semantic borrowing, dialects, custom of Ukrainian non-working Monday, new phraseological meaning

Ключевые слова: фразеология, этимология, чешско-немецкие контакты, калька, диалекты, обычай украинского нерабочего понедельника, новое фразеологическое значение

\section{Abstract}

The article is dedicated to the origin of the Czech phraseological unit modré pondèli 'blue Monday' within its two meanings: an archaic one 'not to work on a Monday' and a new one 'the most depressing day of the year'. Through the study of documents and works on the history of crafts in Bohemia, as well as dialect vocabulary, the origins of this custom are clarified. The author develops the etymological hypothesis by the Brothers Grimm. The name 'blue' is connected with the rites of medieval carnival before the beginning of the Lent. For the first time, a comparison is made with the tradition of a work-free Monday, which existed in Ukrainian folk culture only for married women, and this right was stipulated in the marriage contract. Based on a combination of linguistic, historical and ethnographic data, the author comes to a conclusion that the common theme of a „Blue Monday” for Germanic and Slavic people has developed twice: in one case, as a fragment of the medieval tradition, and in the other, as an element of the modern marketing technique, taking into account the blue symbols and a superstitious view of Monday as a hard day of the week.

Статья посвящена вопросу о происхождении чешского фразеологизма modré ponděli 'синий понедельник' в двух его значениях: архаическом 'не работать в понедельник' и новом 'самый депрессивный день в году'. Благодаря изучению документов и работ по истории ремесел в Богемии, а также диалектной лексики выясняются истоки обычая. Автор развивает этимологическую гипотезу братьев Гримм. Название „синий” связано с обрядами средневекового карнавала перед началом Великого поста. Впервые проводится сопоставление с традицией свободного от работы понедельника, которая существовала в украинской народной культуре только для замужних женщин, причем это право оговаривалось в брачном договоре. На основе совокупности лингвистических, исторических и этнографических данных автор приходит к выводу, что общий для германцев и славян мотив „синего понедельника” развивался дважды: в одном случае как фрагмент средневековой традиции, а в другом - как элемент современного маркетингового приема с учетом символики синего цвета и суеверного представления о понедельнике как тяжелом дне недели.

Чешский фразеологизм modré pondělí 'синий понедельник' по своему происхождению связан с давними историческими реалиями. Этимологическое изучение этого образного выражения насчитывает более ста лет. Выдвинуто несколько гипотез, в которых предпринимались попытки объяснить, почему нерабочий день когда-то был понедельником да еще „синим”, но ни одна из них не может претендовать на абсолютную точность и достоверность, хотя в качестве определенных шагов к накоплению материала такие лингвистические раскопки по крупице воссоздают картину языка в проекции на его культуру (см. напр., Мокиенко 1990). Общим местом в изучении проблемы стало признание того, что в чешском языке оборот modré pondělí или modrý pondělek - калька немецкого der blaue Montag. Такая преемственность вполне убедительна, поскольку соседи-немцы в разные исторические периоды оказывали влияние на социально-экономическое развитие Чехии, что закономерно отразилось на лексике и фразеологии чешского языка. Для самого же немецкого языка история фразеологизма о синем понедельнике окончательно не раскрыта. И эту неопределенность унаследовал его чешский преемник.

Проследить историю „синего понедельника” удается благодаря изучению документов и работ по истории ремёсел в древней Богемии. Так, в них имеется указание, что уже в 1410 г. 
пражские подмастерья не работали в понедельник (světili ponděli) (Winter 1906, с. 746). Важный комментарий находим в уставе 1446 г., который регулировал взаимоотношения масте- ровремесленников и подмастерьев:

С давних времен „по важным причинам” сохраняется право подмастерьев отдыхать кроме воскресения еще и в понедельник (в послеобеденное время с 3-4 часов). От того, что этот день праздновали, понедельник называли „праздничным”, по-немецки der gute (blaue) Montag (Winter 1906, с. 746).

Таким образом, в средневековой Чехии обычай отмечать или праздновать понедельник сложился к середине XV века. В средневековой Германии традиция складывалась таким образом, что сначала понедельник назывался der gute, lustige Montag, а затем получил определение „синий” - der blaue Montag (Winter 1906, c. 216). Авторитетный чешский этнограф Ченек Зибрт отмечал, что обычай неукротимого празднования подмастерьями ,добрых понедельников" был известен во всей центральной Евpoпe: „Bujnostem nezbedné čeládky nebylo míry, ani konce” (Zíbrt 1889 , с. 185). Вышеупомянутые „важные причины” празднования понедельника, его обозначение как веселого, смешного (der lustige Montag) позволяет предположить, что речь шла о традиции средневекового карнавала или славянского мясопуста (чеш. masopust) - праздника, связанного с маскарадом, весельем, переодеваниями, пиршествами перед Великим постом (детальнее см. Даниленко 2000, с. 36-39). Кульминацией мясопуста являлись три последние дня: воскресение, понедельник и вторник. Мясопуст (у чехов период от Tří králů до Popeleční středy) имел официальную и неофициальную части: первая была связана с выполнением определенных церковных ритуалов, а вторая заключала в себе народно-развлекательные формы. Согласно официальной части в мясопустный понедельник (masopustni ponděli) алтари в храмах украшали тканью синего цвета (или фиолетового: не будем останавливаться на проблеме их соотношения). Отсюда название понедельника - синий. Версию о таком происхождении выражения der blaue Montag в немец- ком языке предложили в своем словаре братья Якуб и Вильгельм Гримм:

Синий понедельник, первоначально понедельник перед Пепельной средой, так назван по цвету покрова алтарей в церквях [der blaue Montag, ursprünglich der Montag vor Aschermittwoch, so genannt von der Farbe der Altarumhängung in den Kirchen] (DWG).

Такое же объяснение находим и у чешских авторов: udělat si tučné pondělí (Zaorálek 2000, c. 274; Flajšhans 2013, с. 210), во Франции эти дни назывались Mardi gras, в немецких странах Fastnacht. М. М. Бахтин подчеркивал существенную генетическую связь карнавала с древними языческими празднествами аграрного типа, включавшими в свой ритуал смеховой элемент (Бахтин 1990, с. 244). Энциклопедия Й. Отто приводит толкование:

Синий понедельник - народные гуляния во время мясопустного понедельника, название, заимствованное у немцев, связано с церковным обычаем украшать во время поста алтарь синей тканью в понедельник после Esto mihi [Modrým pondělkem slul po Němcích pondělek masopustní, provázený slavnostmi lidovými. Jméno odvozuje se od zvyku církevního ověšovat v postě oltáře modrou látkou již v pondělí po Esto mihi] (Otto 1903, c. 212),

где Esto mihi - в католической церкви обозначение 7-го воскресенья перед Пасхой по началу мессы этого дня. Украшение же алтаря тканью синего цвета могло корениться в том обстоятельстве, что понедельник согласно древним, еще языческим верованиям считался днем Луны (лат. dies lunae, secunda sabbati) (DWG), отсюда и нем. der Montag, англ. Monday от Mond 'луна', Tag, day 'день'.

Стоит отметить, что синий цвет имеел свою символику также в иудейской религии. Национальный еврейский праздник Пурим содержит элементы языческой карнавальной культуры, а синий цвет связан с одной из заповедей, по которой предписывается прикреплять к краям еврейского молитвенного покрывала (таллита) прямоугольной формы особые кисти: хотя бы одна из ее нитей должна быть синей или голубой. Облачение в таллит рассматривается как символическое подчинение воле 
Бога. Возможно, карнавал и Пурим в древние времена имели какую-то генетическую связь.

Естественно, что с принятием христианства церковь, провозгласив незыблемыми законы нравственности, вела борьбу со вседозволенностью карнавальных традиций. А символику синего цвета сумела подчинить своим догматам: он воплощал идею небесной силы, вечности, Божественного присутствия.

Средневековую традицию синего понедельника разъяснял чешский журнал „Обнова”:

[...] kolem r. 1500 panoval obyčej, že řemeslníci v čase postním prodlužovali svoji pobožnost ve fialově zdobených chrámech od neděle na pondělek i dovolovali také mistři svým tovaryšům, aby $\mathrm{v}$ pondělí od práce ustáli a modrými látkami ozdobeni chrámy navštěvovali. Zvyk tento nazýval se držeti modrý pondělek. To rozšiřrilo se po všech chrámech a modrý pondělek zachovával se i mimo čas postní („Obnova” 1903, c. 5).

О синем понедельнике народ слагал шуточные рассказы, притчи и даже анекдоты, напр.:

- „Houžvičko, vyjmenuj všechny velké posty”.

- „Zelený čtvrtek, velký pátek, bílá sobota - a modrý pondělek”.

- „Cože, modrý pondělek?! Co chceš tím říci?"

- „Prosím to: udělá-li si tatínek o svátcích modrý pondělek, že nezbude mamince nic na oběd" (Duch času 1899, c. 457).

О том, что семантика чешского фразеологизма modré pondělí связана с определенным праздником, свидетельствует также глагольный синонимический ряд этого выражения, cp.: slavit, držet, světit modrý pondělek / modré pondělí (SČFI 673) со значением 'праздновать, придерживаться традиции, проживать день согласно установившемуся обряду'.

Высказывалась также гипотеза, что средневековые подмастерья, чрезмерно обремененные работой, требовали не сокращения рабочего дня, а увеличения количества свободного времени в форме предоставления им дополнительного, кроме воскресения, выходного дня на неделе. Почему им стал именно понедельник? Как отмечала в своем исследовании В. В. СтоклицкаяТерешкович,
[...] наиболее вероятным кажется нам предположение, объясняющее требование свободного понедельника тем, что это был традиционный день всех цеховых собраний, а, следовательно, по мере того как союзы подмастерьев получили законное признание, и всех собраний подмастерьев. [...] Каково бы ни было происхождение указанного требования, факт тот, что оно неизменно выдвигалось подмастерьями и наделало много шуму. Идя из глубины средних веков, оно перешло в XVI и XVII вв. (Стоклицкая-Терешкович 1933, с. 46-47; Лаптева 1999, с. 227-238).

В развитие этой версии служит объяснение, что название modré pondělí происходит от ежегодного цехового воскресного торжества, после которого в понедельник цеховое братство устраивало так называемую синюю литургию в память о товарищах, которые с ними раньше работали. Цвет понедельника в этом случае был назван по цвету синего облачения священнослужителя (SNČ 2006, с. 234).

Можно предположить, что одними из первых право на выходной день в понедельник получили подмастерья-портные. В центральных чешских диалектах, в районе Кладно, синий понедельник назывался ševcovský den: [f poděli maj šeu्रcousskej den] (Kubín 1913, с. 171). Эту же тему актуализирует чешская пословица Každá víra jinač světí: Turci v pátek, židé v sobotu, křest’ané v neděli a ševci v ponděli (Čelakovský 1949, c. 615), сходную мотивацию имеют пословицы в украинском и польском языках: Понеділок - иевський празник (Жайворонок 2018, с. 499), W роniedziałek wszyscy szewcy świętuja (Adalberg 1889-1894, c. 421).

Со временем традиция бурно проводить синий понедельник, обязательно с употреблением алкоголя, прочно вошла в быт всех ремесленных цехов - пекарей, мясников, золотарей, шляпников и т. п. - и превратилась в плохую привычку (zlozvyk), против которой власти стали вести борьбу, издавая запреты и законы:

Jelikož se však řemeslníci místo modlení a pobožnosti později pití a zahálce oddávali, dal císař Maxmilián II. (1564-1567) rozkaz, aby se tomuto zlořádu př́trž učinila. Rozkaz ten zůstal však bez účinku a až po dnešní den slaví se u nás až př́liš oblíbený „modrý pondělek” („Obnova” 1903, c. 5); 
[...] ač státy zakročovaly proti této zvyklosti po staletí, udržela se až po naši dobu (Otto 1903, c. 212).

Таким образом, первичная положительная „маскарадная” семантика фразеологизма modrý pondělek получила дополнительную коннотацию „не работать в понедельник после воскресных кутежей; прогуливать рабочий день”, ср.: „,blau” má zde význam expr. 'podnapilý, neschopný práce (po nedělní pitce)' (Holub, Lyer 1968, c. 384), Pondělek jest nedělin bratr (Čelakovský 1949, c. 167), нем. blau sein „быть вдребезги пьяным” (Бинович 1995, c. 104). В комедии Йозефа Каетана Тыла „Фидловачка” (Јоsef Kajetan Tyl, Fidlováčka) имеется замечательный диалог мастера и подмастерья: „ک̌vec tovaryš: Víš, co modré pondělí? - Švec učeník: Když se starej ochmelí” (Tyl 1880, c. 252).

Характерно, что в чешском языке отмечено несколько слов, ныне архаичных, связанных с семантикой фразеологизма modrý pondělek: это глаголы modřiti и pondělkovati 'držet modrý pondělek, nic nedělat, nebýt v práci': pondělkovat 'blauen Montag halten' (Jungmann 1837, c. 287), Zitra budeme modřit (Bolech 1913, c. 308), Tovaryš nepřišel, a nikdo se tomu nedivil, věda, že drži modré pondělí anebo že pondělkuje, jak se také ríká (PSJČ), cp. нем. blauen Montag machen 'прогулять, не выйти на работу' (Бинович 1995, c. 104), пол. poniedziałkowanie 'pijatyka majstrów rzemieślniczych (szewskich) w poniedziałki’ (Karłowicz 1906, c. 254), Wón trzymá dzys szewiecki póniedzétk (Adalberg 1889-1894, c. 421).

В современном чешском языке фразеологизм mit, držet modré pondělí расширил свое значение, в котором присутствует нейтральная коннотация 'иметь выходной день', напр.: Práce je na muzikálu tolik, že si plánujeme, jak bychom si užili svůj volný den. Já mám modré pondělky - jediný den, kdy nehraju (ČNK, syn v8). Поэтому, отвечая на вопрос А. А. Парфеновой „Синий понедельник - пьяный или ленивый?" (Парфенова 2015), можно ответить, что семантика развивалась по цепочке: праздничный и веселый < нерабочий и пьяный < обычный выходной.
В плане типологического сопоставления мотива отдыха в понедельник представляет интерес украинская лексема понеділкувати. Кроме значения 'не работать, а отдыхать в понедельник', как, например, в пословице Захотіла баба, понеділкувавши, трудодень мати (УНПП 1955, с. 392), традиция понедельничать в украинской народной культуре, известная до начала XX в., имела три важные черты, заставляющие глубоко задуматься над ее истоками, а именно: во-первых то, что понедельничание не приурочивалось к каким-либо праздникам или постам, а совершалось без очереди, каждый понедельник; во-вторых, что оно практиковалось только среди женщин и притом исключительно замужних; в третьих, и что особенно достойно замечания, право понедельничать закреплялось особой статьей в предбрачном договоре. Во время сватания родители невесты объявляли сватам, какое приданое дают за дочерью, и сразу же выговаривали для нее право понедельничать, то есть быть свободной в понедельник от обычной домашней работы. „По установившемуся обычаю, самый строгий и взыскательный супруг не имел права заставить жену исполнять хозяйственные работы в понедельник. Так установилось „с предков” (Василенко 1887, с. 181). На поддержании понедельничания особенно настаивали матери, мотивируя тем, что их „бабки и матери понедельничали и нам наказали". При этом женщины в понедельник не сидели дома, сложа руки. Они шли на базар торговать всякими продуктами своего подсобного хозяйства - мукой, горохом, фасолью и т.п., а затем отправлялись на гуляния „для выпивки. В летнее время все эти „понедельничающие” женщины усаживаются на открытом воздухе, а зимой в хате, и начинается круговая...” (Василенко 1887, с. 182).

Анализируя обычай украинского понедельничания, распространенного до начала XX в. только в г. Борисполе Полтавской губернии, Н. Чернышев высказал гипотезу, что его возникновение своими корнями уходит в отдалённейшую первобытную эпоху жизни человечества, при которой все женщины данного 
племени считались состоящими в браке со всеми мужчинами того же племени (брак так называемого „первобытного коммунизма”). „Что в жизни славянского племени была эпоха, в которую брачные отношения носили характер очерченного выше общинного брака, - пишет Н. Чернышев, - можно было предполагать уже из преданий, занесенных в хроники; таким является, например, предание чешского народа, записанное Козьмой Пражским" (Чернышев 1887, с. 767). Истоки понедельничания Н. Чернышев усматривает в первоначальном обычае заключать брак „на три четверти”, согласно которому женщина в определенный день освобождалась от супружеских обязанностей. После того, как брачные отношения окончательно сложились по моногамному типу, эротический элемент исчез, а на смену ему пришел трудовой или экономический. С течением времени и эта форма свободы от труда претерпела изменения, превратившись в обычай соблюдать пост в понедельник. В середине XIX в. в украинском языке было распространенным выражение понеділкова жінка - 'женщина, придерживающаяся обычая понедельничания’ (Грінченко 1958, с. 310). Однако уже в начале XX в. известный этнограф Н. Сумцов констатировал отмирание обычая понедельничания среди женщин: „Соблюдение поста по понедельникам... ныне местами практикуется старыми женщинами, с личным приурочением старого обычая (выделено нами - Л. Д.) к Святому Понедилку" (Сумцов 1905, с. 27). У православных христиан „святым” или „рождественским” назывался первый понедельник после Крещения, когда надлежало соблюдать пост, отсюда пословица Святий понеділку, не сварись на мене, щзо я n'ю горілку! (Воропай 1991, с. 178). Следует подчеркнуть, что данный пост не был церковным, а связывался исключительно с символикой понедельника. Первый понедельник после православного Крещения (19 января) в хронологическом плане соответствовал началу мясопуста в католической церкви: праздник Трех королей приходится на 6 января („Тйі krále 6. ledna", PSJČ), а католический мясопуст (masopustní ra- dovánky), как выше упоминалось, начинался именно с праздника Трех королей. Учитывая разницу между юлианским и григорианским календарями, можно утверждать, что святой понедельник и мясопусm первоначально имели одинаковые празднично-карнавальные дохристианские языческие корни и восходили к ритуалам проводов Зимы и встречи Весны.

Таким образом, материалы украинских этнографических, лексикографических и литературных источников свидетельствуют о том, что в украинском языке слово понеділкувати, ныне устаревшее, поначалу имело значение 'соблюдать обычай среди женщин не работать в понедельник', а затем - 'соблюдать пост в понедельник', который по народной, а не церковной, традиции предписывался как женщинам, так и мужчинам. В одном месте „Энеиды” И. Котляревского (первое издание поэмы 1798 г.) имеется краткое упоминание о понедельничании, которое уже касается мужчин: Iди, небого, не журися, Попонеділкуй, помолися (Котляревський 2011, с. 57). Любил понедельничать и соблюдать посты герой повести И. Нечуя-Левицкого „Кайдашева семья" старый Омелько.

Древний обычай не работать по понедельникам осуждался в народном славянском фольклоре, ср. рус.: Понедельник - бездельник, вторник - подворник (подворник - человек, праздно шатающийся по дворам), Лучше не понедельничать да не бездельничать (БСРП, с. 690), пол. Kto poniedziałek przepróżnuje, we wtorek nie będzie miat co jeść (Adalberg 1889-1894, c. 421). Хотя был ли такой обычай у этих народов или пословицы к ним пришли из других этносов, этот вопрос требует дополнительного исследования.

Архаичный обычай синего понедельника в наше время развивает новое толкование. Синим понедельником стали называть самый депрессивный день в году. Примечательный факт, что современный синий понедельник, как и Великий пост, - не имеет фиксированной даты в календаре. Ежегодно он приходится на третий понедельник января. Эту дату вычислил в 2005 г. бри- 
танский психолог Клифф Арналь с помощью математической формулы, которая содержит метеорологические данные (короткий солнечный день, низкий уровень солнечной энергии), психологические данные (низкий уровень мотивации, неоправдавшиеся надежды на начало нового года) и экономические (дисбаланс личного бюджета, разница между долгами и платежеспособностью человека). Вера в негативное воздействие этого дня на настроение людей приобрела такие масштабы, что в отдельных странах стали проводить мероприятия с целью поддержания психического здоровья соотечественников. Языковым маркером нового понятия является английское словосочетание blue Monday, которое в славянских языках употребляется как калька, напр. укр. блакитний понеділок, рус. голубой понедельник, блр. сіні панядзелак, пол. niebieski poniedziałek. В чешском языке, судя по периодическим изданиям, пока употребляется как английский, так и калькированный вариант, ср.: Nejdepresivnějši den v roce je tady: Blue Monday mũže být zrádné; Cliff Arnall Modré pondělí vypočítal na zakázku pro cestovní kancelář Sky Tra$v e l$. Несомненно, что семантическая мотивированность современного фразеологизма modré ponděli/ blue Monday не имеет никаких общих корней со средневековым „синим понедельником" и скорее всего заключается в суеверном представлении о понедельнике (Понедельник - день тяжельй, это самая распространенная пословичная характеристика этого дня) и символике колоратива синий - самого холодного цвета, ассоциирующегося, как правило, с пустотой, холодом, уходом в вечность, созерцанием, пассивностью и т. п. М. Фасмер считал слово $\mathrm{cu}$ ний заимствованием из древнеиндийского с̧уа̄más 'черный, темный' (Фасмер 1987, с. 624), отсюда англ. blue funk/fear 'паническое состояние, сильный испуг, жуткий страх' и blue Monday 'в школьном жаргоне - первый день занятий после каникул', нем. eine Fahrt ins Blaue 'поездка в никуда'. Фразеологических примеров негативной коннотации цветообозначения синий достаточно много в разных языках.
Между тем история „синего понедельника” сыграла свою положительную роль в новое время. Традиция предоставления выходного дня в понедельник, особенно после государственных или календарных праздников (Рождества, Нового года, Паски), вероятно является отголоском средневековой борьбы подмастерьев за право отдыхать в понедельник.

На основании вышеизложенного можно выдвинуть осторожное предположение, что мотив не работать в понедельник - общеевропейский мотив, возникший, по крайней мере, в раннюю средневековую эпоху. В этом случае германские и славянские языки являются равными наследниками этого мотива. В дальнейшем судьба понедельника раздваивается. С одной стороны, в средневековой западноевропейской традиции он оказывается связанным с карнавальными традициями, цеховым братством ремесленников, прежде всего портных. Германская культура послужила проводником „,синего понедельника” на чешскую почву. С другой стороны, в народной культуре украинцев этот день первоначально связывался с женским „братством”, правом отдыха в понедельник только для замужних женщин, причем это право оговаривалось в брачном договоре. Перед нами, как представляется, любопытный лингвокультурный феномен: общий для германцев и восточных славян мотив свободного от работы понедельника, раздельно усвоенный культурными традициями и языками этих народов, впоследствии дважды развивается германской и славянской культурами: в одном случае как фрагмент средневековой традиции, а в другом - как элемент современного маркетингового приема с учетом символики синего цвета и суеверного представления о понедельнике как тяжелом дне недели.

\section{Сокращения}

ČNK $\quad$ Český Národní Korpus. URL: http://ucnk.ff.cuni.cz. Дата доступа: 28.04 .2020

DWG Deutsches Wörterbuch von Jacob Grimm und Wilhelm Grimm. URL: http://woerterbuchnetz.de/cgi-bin/WBNetz/wbgui_py?sigle= 
DWB\&mode=Vernetzung\&lemid=GM06990\#XGM06990. Дата до-

PSJČ

\section{ступа: 28.04 .2020$.} доступа: 25.04.2020.

SČFI 1994 Slovník české frazeologie a idiomatiky. Sv. 3, Výrazy slovesné, 1. vyd., část 1.: A-P, Praha: Academia.

SNČ 2006 Slovnik nespisovné češtiny: argot, slangy a obecná mluva od nejstaršich dob po současnost: historie a pưvod slov, hl. ed. J. Hugo. Praha: Maxdorf.

БСРП 2010 Мокиенко В. М., Никитина Т. Г., Николаева Е. К. Больщой словарь русских пословиц. Москва: ЗАО „ОЛМА Медиа Групп”.

УНПП 1955 Українські народні прислів'я та приказки, відп. ред. М.Т. Рильський, Київ: Видавництво АН УРСР.

\section{Литература}

A d a l b e rg S., 1889-1894, Ksiega przysłów, przypowieści i wyrażeń przystowiowych polskich. Warszawa: z zapomogi Kasy Pomocy dla Osób Pracujących na Polu Naukowym im. d-ra J. Mianowskiego.

B ole c h V., 1913, Dialektologické paběrky z okoli Netolic. „Český lid” XXII, s. 307-308.

Č e l a k o v s k ý F. L., 1949, Mudrosloví národu slovanského ve príslovích. 3. vyd. Praha: Vyšehrad.

„Duch času” XXIX, 1899, 16.04

F 1 a j š h a n s V., 2013, Česká přisloví: sbirka př́sloví a pořekadel lidu českého $v$ Cechách, na Moravé a v Slezsku: prislovi staročeská, vybral a usporádal Václav Flajšhans; editoři Valerij Mokienko, Ludmila Stěpanova, 2 sv.; 2. , rozš. vyd., Olomouc: Univerzita Palackého v Olomouci.

H o lu b J., Lye r S., 1968, Stručný etymologický slovník jazyka českého se zvláštním zřetelem $k$ slovi̊m kulturním a cizím. 2. vyd. Praha: Státní pedagogické nakladatelství.

J u n g m a n n J., 1837, Slownjk česko-německý. D. III. W Praze: Pomocj Českého Museum.

K a r ło w i c z J., 1906, Stownik gwar polskich. Kraków: Akademia Umiejętności, t. 4 .

K u bín J., 1913, Lidomluva Čechủ Kladských. Př́spěvek $k$ české dialektologii. V Praze: Nákladem České akademie císaře Františka Josefa pro vědy, slovesnost a umění.

„Obnova” XLIV, 1903, 30.10.

O t to J., 1903, Ottův slovnik naučný. Ilustrovaná encyklopedie obecných vědomostí. D. 20. V Praze: J. Otto.

Ty 1 J. K.,1880, Sebrané spisy, sv. 12, Národní kněhtiskárna I. L. Kober.
W i n te r Z., 1906, Dějiny řemesel a obchodu v Čechách v XIV. a v XV. století. V Praze: Nákladem České akademie císaře Františka Josefa pro vědy, slovesnost a umění.

Z a o r á 1 e k J., 2000, Lidová rčení. 4. vydání. Praha: Academia.

Zí b r t C.. 1889, Staročeské výroční obyčeje, pověry, slavnosti a zábavy prostonárodni pokud o nich vypravuji písemné památky až po náš věk: Přispěvek ke kulturním dějinám českým. Praha: Josef R. Vilímek.

Б а х т и н М. М., 1990, Творчество Франсуа Рабле и народная культура средневековья и Ренессанса, Москва: Художественная литература.

Б и н о в и ч Л. Э., 1995, Немечко-русский фразеологический словарь, Москва: Аквариум.

В а с и ле н ко В., 1887, Празднование понедельника в Малороссии. Киевская старина. Год шестой. T. XVII. Январь-Апрель 1887 г., с. 180-182.

В о р о п а й О., 1991, Звичаї намого народу. Етнографічний нарис. Т.1. Київ: Оберіг.

Гр і н ч е н ко Б., 1958, Словарь украӥнської мови, т. 3. Київ: Видавництво АН УРСР.

Дан и лен ко Л. I., 2000, Начіонально-культурна семантика чеської фразеологіï. Київ: Інститут мовознавства ім. О. О. Потебні НАН України.

Ж а й в о р о н о к В., 2018, Антологія знаків украӥнської етнокультури. Словник-довідник. Київ: Наукова думка.

К о т л я р е в с ь к и й I., 2011, Енеїда. Харків: Фоліо.

Л а п т е в а Л. П., 1999, Особенности устава и функиионирования немечкого ремесленного цеха XVI века в Северной Чехии. [В:] Славяне и их соседи. Вып. 9. Славяне и немиы. Москва: Наука, с. 227-237.

М ок и ен ко В. М., 1990, Черные дни и голубые понедельники. [В:] Загадки русской фразеологии. Москва: Высшая школа, с. 44-46.

Пар фе н о в а А. А., 2015, Синий понедельник - пьяньй или ленивый? [B:] Этнолингвистика. Ономастика. Этимология: Материалы III Международной научной конференции Екатеринбург, 7-11 сентября 2015 г. Екатеринбург: Издательство Уральского университета, с. 208-210.

С то к л и ц к а я - Т е р ешк о в и ч В. В., 1933, Немеикий подмастерье XIV$X V$ веков. Ленинград: Издательство Академии наук СССР.

С у м ц о в Н., 1905, Бытовая старина в «Энеиде» И. П. Котляревского. [В:] Н. Сумцов, Из украинской стариныл. Харьков: Типография „Печатное дело" кн. К. Н. Гагарина, с. 14-35.

Ч ернышев Н., 1887, Опыт истолкования обычая «понедилкуванья». Киевская старина. Год шестой, т. XVII. Январь-Апрель 1887 г., с. 763-771.

Ф а с м е р М., 1987, Этимологический словарь русского языка. Изд. 2-е, стереотип., т. 3. Москва: „Прогресс”. 